\title{
Atmospheric Impact Analysis of Work on Employee Performance Through Aspects of Employee Welfare
}

\author{
Agustiawan Djoko Baruno', Meithiana Indrasari², Dandy Patrija Wirawan ${ }^{3}$, Jovi \\ Iristian $^{4}$ \\ \{agustiawanb@unitomo.ac.id ${ }^{1}$, meithiana.indrasari@unitomo.ac.id ${ }^{2}$, dandypatria@yahoo.com ${ }^{3}$ \} \\ ${ }^{1,2,4}$ Fakultas Ekonomi dan Bisnis, Universitas Dr.Soetomo, Indonesia \\ ${ }^{3}$ Fakultas Ilmu Administrasi, Universitas Dr.Soetomo, Indonesia
}

\begin{abstract}
The purpose of this research is (1) to find out how the influence of work atmosphere towards employee performance at Dr. Soetomo University Surabaya; and (2). To find out whether employee welfare variable as a mediation variable between the influence of work atmosphere on employee performance at Dr. Soetomo University Surabaya. The design of the study explains the importance of information needed in preparing or solving research problems. The sample in this research is $70 \mathrm{Dr}$. Soetomo employees who are still active semester Academic Year 2016/2017 from 8 faculty with Proportionate Stratified Random Sampling technique. The results showed (1) there was a significant positive impact of Work Atmosphere on employee performance at Dr. Soetomo University Surabaya and (There is a significant impact of employee welfare variable as a variable mediation between the influence of work atmosphere on employee performance at Dr. Soetomo University Surabaya).
\end{abstract}

Keywords: Work atmosphere, employee welfare, employee performance.

\section{Introduction}

Dr. University Soetomo is determined to participate in other components of the nation to increase participation in building an intellectual community that is trustworthy, capable of mastering, and skilled in utilizing science and technology, to support the realization of optimal university management performance.

To conduct all operational activities of universities, human resources are needed. In this case, knowledge of how to direct employees is needed so that they can work as much as possible. To be able to realize this goal, a university must be able to create a working atmosphere well[1]. So that in carrying out a job the employee can be motivated and willing to work hard, and be supported with an increase in employee welfare. Then it will achieve the objectives of the higher education organization.

Therefore, the University of Dr. Soetomo Surabaya can compete with other universities, the University of Dr. Soetomo must be able to provide a work atmosphere and a good level of prosperity so that it can affect the performance of employees which ultimately achieves organizational goals.

The formulation of the problem in this study is (1) How does the influence of work atmosphere on employee performance at the University of Dr. Soetomo Surabaya, (2) What is the employee welfare variable as a mediation of the influence of work atmosphere variables on employee performance at the University of Dr. Soetomo Surabaya? 
The purpose of this study is (1) to find out how the influence of work atmosphere on employee performance at the University of Dr. Soetomo Surabaya; and (2). To find out whether the employee welfare variable is a mediating variable between the influence of the work atmosphere on employee performance at the University of Dr. Soetomo Surabaya.

\section{Literature Review}

\subsection{Work Atmosphere}

According to Nitisemito[2] The atmosphere of work is that the existing working conditions are pleasant, comfortable, and safe for every employee in it. So that it can be said that the atmosphere of work (work atmosphere) is a condition that exists around employees who are doing work that can affect the implementation of the work itself. The work atmosphere consists of workplaces, facilities, and tools for work, cleanliness, lighting, tranquility, including work relations between people who are there.

\subsection{Employee Welfare}

Employee welfare is an award given to employees in the form of salary or salary. Saydam [3] suggested several aspects of employee welfare consisting of salaries, wages, benefits, and incentives or bonuses. This allowance can be in the form of family allowances, development benefits, and so on, which essentially increases employee income.

\subsection{Employee Performance}

Mangkunegara [4] which states that employee performance is the result of work in quality and quantity that is achieved by an employee in carrying out their duties by the responsibilities given. Rival and Basri [5] which states that performance is the result or the level of success of a person as a whole over a period of time in carrying out tasks compared to various possibilities, such as standard work results, targets or targets that have been determined and agreed upon[6].

Employee performance in this study was measured through several indicators that adopted several performance appraisal theories by several experts namely Robert L. Mathis [7], Gary Dessler [8], Faustino Cardoso Gomes [9], Malay SP Hasibuan [10] and Suprayitno research and Sukir [11] who adopted Miner's performance appraisal theory. Based on some of these opinions, the indicators that will be used in this study consist of the quality of work, quantity of work, timeliness, and collaboration.

\subsection{Development of Hypotheses}

According to Nogra [12] the hypothesis is a temporary answer to the research problem until proven through the collected data. It is said temporarily because the answers given are only based on relevant theories, not yet based on empirical data obtained through data collection. So the hypothesis can also be stated as a theoretical answer to the formulation of research problems and there are no empirical answers.

The research hypothesis is as follows:

H1: Alleged work atmosphere influences employee performance at the University of Dr. Soetomo Surabaya

H2: Allegedly employee welfare as a mediating variable between the influence of variable work atmosphere on employee performance at the University of Dr. Soetomo Surabaya 


\section{Method}

\subsection{Research Design}

The research design is a study that explains the important procedures for getting the information needed in compiling or solving research problems [13]. The main method of this research is survey research, which is a study conducted by taking samples from the population and questionnaires as a basic data collection tool [14][15].

\subsection{Scope of Research}

This research is to analyze the impact of work atmosphere on employee performance through aspects of employee welfare. This research was conducted at the University of Dr. Soetomo.

\subsection{Research Sites}

This research site is on Jl. Semolowaru No.84, Menur Pumpungan, Sukolilo, Kota Surabaya, 60118, East Java, Indonesia. The initial survey was conducted in April 2017, while the research data collection was conducted in July 2017 - August 2017.

\subsection{Data Collection Techniques}

The technique of collecting data through questionnaires. The questionnaire is a series of statements submitted directly to the respondent to be answered. In this case, the research uses a type of structured statement, namely a statement made in such a way that the respondent is limited in giving answers. In this study, the questionnaire contained structured questions regarding work atmosphere variables, employee welfare, and employee performance.

The sample in the study were 70 employees Dr. Soetomo who is still active in the 2016/2017 Academic Year semester from 8 faculties with the Proportionate Stratified Random Sampling technique. To determine the size of the study sample refers to the sample measurement guidelines [16], which can be determined as follows: (1) The sample size can be around 100-200 samples in the study; (2) Depends on the estimated parameter number. The guidelines are 5-10 times the number of parameters estimated.

So the sample number $=14 \times 5$ (number of parameters $)=70$ employees. Thus the sample of students from 8 faculties also numbered 70 employees.

\subsection{Operational Definition of Research Variables}

To further clarify the meaning of the research variables identified above, the variables can be defined as follows:

a. Work atmosphere (work atmosphere) is a condition that exists around employees who are doing work that can affect the implementation of the work itself. The work atmosphere indicator (work atmosphere) in this study is measured from the workplace, facilities, and tools for work, hygiene, lighting, calm, including work relations between the people in the place.

b. Employee welfare is an award given to employees in the form of salary or salary. Welfare in research is measured by salary, wages, benefits, and incentives or bonuses.

c. Employee Performance is the embodiment of work carried out by employees who are usually used as a basis for evaluating employees or organizations [10]. Employee performance in this study was measured through several indicators that adopted several 
performance appraisal theories by several experts namely Robert L. Mathis [7], Gary Dessler [8], Faustino Cardoso Gomes [9], Malay SP Hasibuan [10], and Suprayitno research and Sukir [11] who adopted Miner's performance appraisal theory. Based on some of these opinions, the indicators that will be used in this study consist of the quality of work, quantity of work, timeliness, and collaboration.

\subsection{Analysis Techniques}

The data analysis technique used to answer hypothesis testing using the Structural Equation Model (SEM) using the Smart PLS 3.2.6 package.

Structural Equation Model (SEM) is a set of statistical techniques that allow testing of a series of relations that are relatively complicated simultaneously [16]. PLS is a regressionbased method. PLS assumes that research data is free of distribution (distribution-free), meaning that research data does not only refer to one distribution. PLS is an alternative method of Structural Equation Modeling (SEM) that can be used to overcome the problem of relationships between complex variables but the size of the data sample is small (30 to 100), since SEM has a minimum sample size of 100 [15]. The steps to form a structural equation model (SEM) with the PLS method are as follows:

a. The first step is evaluating the outer model. In evaluating the outer model, testing will be conducted on convergent validity (convergent validity), discriminant validity (discriminant validity), and composite reliability.

b. The second step that must be done, namely evaluating the inner model. In evaluating this inner model, we will explain the R-square results and test the hypothesis. According to Ridwan and Sunarto [17] to be able to test hypotheses, researchers can use the provisions of significance probability numbers, as follows: (1) If the probability of significance is> 0.05 , then: $\mathrm{H} 0$ is accepted, $\mathrm{H} 1$ is rejected, it means no significant, (2) If the probability of significance is $<0.05$, then: $\mathrm{H} 0$ is rejected, $\mathrm{H} 1$ is accepted, it means significant.

\section{Result and Discussion}

\subsection{Results}

Research data analysis Analysis of research data using the Structural Equation Modeling (SEM) approach using Partial Least Square (PLS) analysis method and with the help of SmartPLS 3.2.6 application program because this study uses mediating variables. The stages of SEM analysis are Outer Models and Inner Models, as follows:

\subsubsection{Evaluation of Outer Models}

\subsubsection{Convergent Validity}

Convergent validity of the measurement model with reflexive indicators can be seen from the correlation score item with the variable score. Indicators are declared valid if the correlation value (loading factor) in convergent validity is above 0.5 [3]. The following is a picture measurement model: 


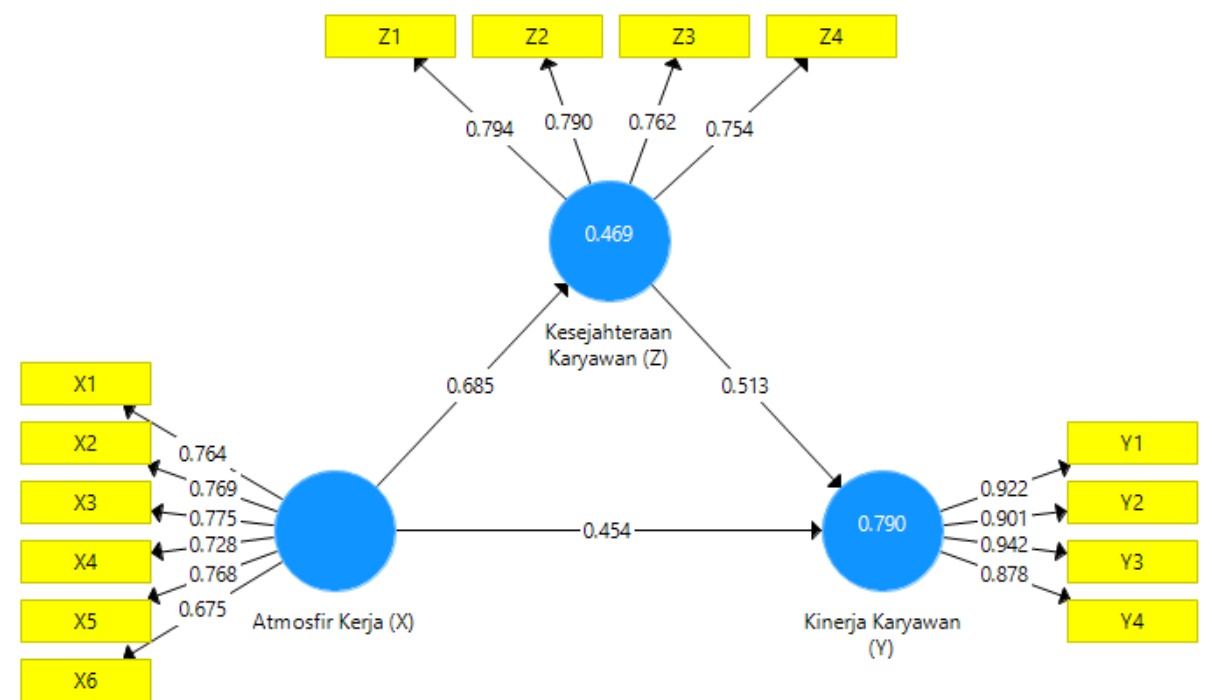

Fig. 1. Measurement Outer Model

Source: Appendix of SmartPLS Output, data processed (2017)

Based on Figure 1 above, the loading factor values of each indicator of the latent variable Work Atmosphere (X), Employee Welfare (Z), and Employee Performance (Y) have met the requirements, or it can be said that the indicator represents or forms the latent variable, because convergent validity (loading factor) is above 0.5 . And based on Figure 1. above, the value of the loading factor of each item can be seen in Table 1 of the following Outer Loadings:

Table 1. Outer Loadings

\begin{tabular}{lccc}
\hline & $\begin{array}{c}\text { Work } \\
\text { Atmosphere }(\mathrm{X})\end{array}$ & $\begin{array}{c}\text { Employee } \\
\text { Welfare }(\mathrm{Z})\end{array}$ & $\begin{array}{c}\text { Employee } \\
\text { Performance (Y) }\end{array}$ \\
\hline X1 & 0.764 & & \\
X2 & 0.769 & & \\
X3 & 0.775 & & \\
X4 & 0.728 & & \\
X5 & 0.768 & & \\
X6 & 0.675 & 0.794 & \\
Z1 & & 0.790 & \\
Z2 & & 0.762 & 0.922 \\
Z3 & & 0.754 & 0.901 \\
Z4 & & & 0.942 \\
Y1 & & & 0.878 \\
Y2 & & & \\
Y3 & & & \\
Y4 & &
\end{tabular}

Based on Table 1 above, it can be seen that the value of outer loadings from 6 dimensions (Workplace (X1), Facilities and job aids (X2), Hygiene (X3), Lighting (X4), Tranquility (X5), and Work relations between the people in that place (X6)) form the Working 
Atmospheric variable $(\mathrm{X})$ greater than 0.50 , meaning the indicators of the Working Atmospheric variable $(\mathrm{X})$ have good convergent validity.

Employee Welfare (Z) is formed from 4 indicators (Salary (Z1), Wages (Z2), Allowances (Z3), and Incentives or bonuses (Z4)), each of which has a value of outer loadings greater than 0.50, meaning indicators of the Employee Welfare variable ( $\mathrm{Z}$ ) has good convergent validity.

Employee Performance (Y) is formed from 4 work quality indicators (Y1), work quantity (Y2), timeliness (Y3) and cooperation (Y4).) Each of which has a value of outer loadings greater than 0.50, meaning indicators from the Employee Performance variable ( $\mathrm{Y}$ ) has good convergent validity.

\subsubsection{Discriminant Validity}

A variable is declared to fulfill discriminant validity if it has an AVE value $>0.50$. The following are the test results of Average Variance Extracted (AVE):

Table 2. Results of Average Variance Extracted (AVE)

\begin{tabular}{ll}
\hline \multicolumn{1}{c}{ Variable } & AVE \\
\hline Work Atmosphere (X) & 0.559 \\
Employee Welfare (Z) & 0.601 \\
Employee Performance (Y) & 0.830 \\
\hline
\end{tabular}

Source: Attachment of SmartPLS 3 Output, data processed (2017)

In Table 2. above, it can be seen that the AVE value for each variable has a value greater than 0.50 . So that it can be stated that the whole variable has met the criteria of discriminant validity.

\subsubsection{Composite Reliability}

Composite reliability tests the value of reliability between the indicator blocks of the constructs that make it up. The following are the results of the PLS composite reliability output:

Table 3. Results of Composite Reliability

\begin{tabular}{lc}
\hline \multicolumn{1}{c}{ Variable } & Composite Reliability \\
\hline Work Atmosphere (X) & 0.883 \\
Employee Welfare (Z) & 0.858 \\
Employee Performance (Y) & 0.951 \\
\hline \multicolumn{1}{c}{ Source: Attachment of SmartPLS 3 Output, data processed (2017) }
\end{tabular}

Source: Attachment of SmartPLS 3 Output, data processed (2017)

Variables are declared reliable if the composite reliability value is above 0.70. Based on Table 3 above, it can be seen that the composite reliability value for all variables is greater than 0.70 . Thus the model variable has complied with composite reliability.

\subsubsection{Inner Model Evaluation}

The structural model (inner model) in PLS is evaluated using R2 for the dependent construct and the Path Coefficients or t-value (t-statistic) values for the test of significance between constructs. The higher the value of $\mathrm{R} 2$ means the better the prediction of the proposed model. Saydam [3] explains the Path Coefficients score or inner model which is indicated by 
the t-statistical value must be above 1.96 for testing hypotheses on alpha (level of research error) of $5 \%$.

\subsubsection{R-square analysis}

Based on data processing with PLS, the determination coefficient value (R-square) is generated as follows: $u$ the inner model shown by the t-statistical value must be above 1.96 for testing the hypothesis on alpha (level of research error) of $5 \%$.

Table 4 Results of $R$-Square

\begin{tabular}{lc}
\hline \multicolumn{1}{c}{ Variable } & R-Square \\
\hline Work Atmosphere (X) & - \\
Employee Welfare (Z) & 0.469 \\
Employee Performance (Y) & 0.790 \\
\hline
\end{tabular}

Source: Attachment of SmartPLS 3 Output, data processed (2017)

In Table 4. above, the model of the influence of Work Atmosphere on Employee Welfare (Z) gives an R-Square value of 0.469 which can be interpreted as construct variability of Employee Welfare $(Z)$ which can be explained by the work atmosphere construct variability of 46.9\%. Whereas $53.1 \%$ is explained by other variables outside the model.

Furthermore, the model of the influence of Work Atmosphere and Employee Welfare on Employee Performance gives an R-Square value of 0.790 which can be interpreted that the construct variability of University Employee Performance Dr. Surabaya Soetomo which can be explained by construct variability of Work Atmosphere and Employee Welfare of 79.0\% while $21.0 \%$ is explained by other variables outside the model.

\subsubsection{Prediction Relevance Test}

Besides looking at the R-square value, the PLS model was also evaluated by looking at Q-Square Predictive Relevance for the constructed model. Suitability of structural models can be seen from Q2, as follows:

$$
\begin{aligned}
\mathrm{Q}^{2} & =1-\left[\left(1-\mathrm{R}_{1}^{2}\right) *\left(1-\mathrm{R}_{2}^{2}\right)\right] \\
& =1-[(1-0.469) *(1-0.790)] \\
& =1-\left[(0.531)^{*}(0.210)\right] \\
& =1-[(0.112)] \\
& =0.888
\end{aligned}
$$

From the above calculation, the predictive relevance Q-square value is 0.888 , where the value is greater than zero. This shows that the model has predictive relevance that can explain the model by $88.8 \%$. 


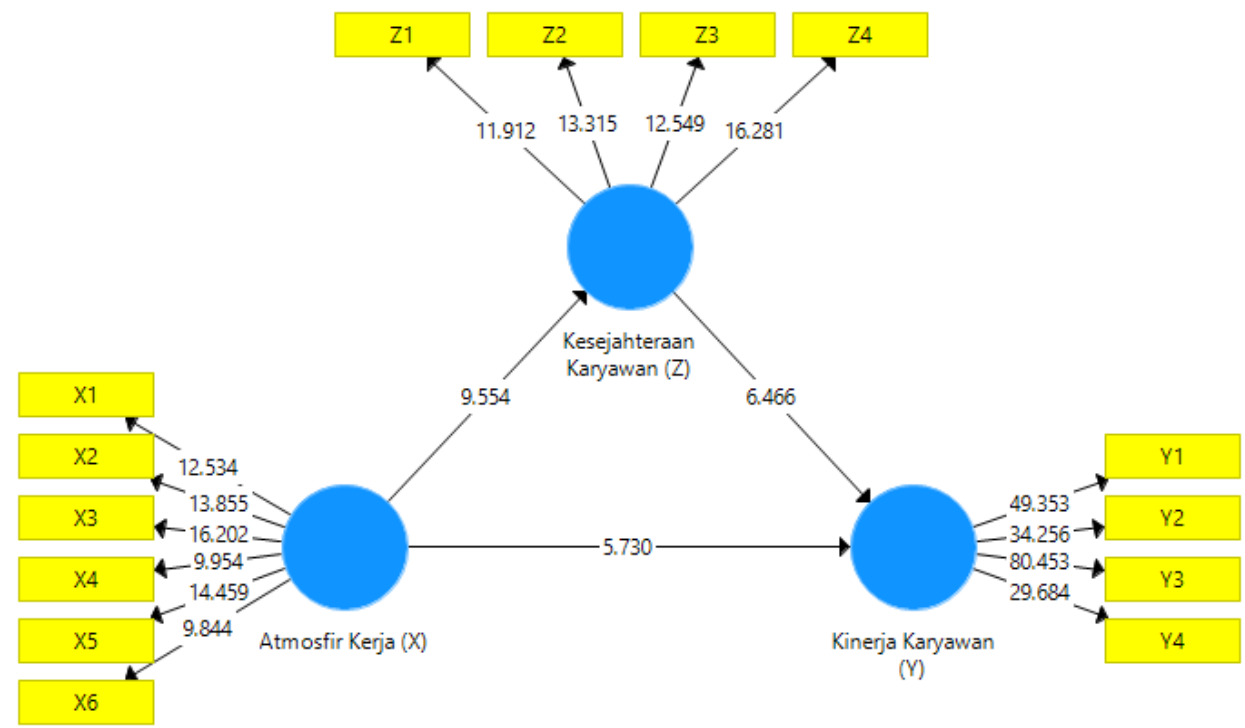

Fig. 2. Measurement Bootstrapping (Inner Model)

Source: Attachment of SmartPLS 3 Output, data processed (2017)

\section{Hypothesis testing}

The inner model can see the relationship between constructs and significance values in the Path Coefficients table as shown in Table 5. below:

Tabel 5. Path Coefficients

\begin{tabular}{|c|c|c|c|c|}
\hline Direct Effect & $\begin{array}{c}\text { Original } \\
\text { Sample }(\mathrm{O})\end{array}$ & $\begin{array}{c}\text { T Statistics } \\
(\mid \text { O/STERR } \mid)\end{array}$ & P Values & Information \\
\hline $\begin{array}{l}\text { Work Atmosphere }(\mathrm{X}) \\
->\text { Employee Benefits } \\
(\mathrm{Z})\end{array}$ & 0.685 & 9.554 & 0.000 & Significant \\
\hline $\begin{array}{l}\text { Employee Welfare }(\mathrm{Z}) \\
->\text { Employee } \\
\text { Performance }(\mathrm{Y})\end{array}$ & 0.513 & 6.466 & 0.000 & Significant \\
\hline $\begin{array}{l}\text { Work Atmosphere }(\mathrm{X}) \\
->\text { Employee Benefits } \\
(\mathrm{Z})\end{array}$ & 0.454 & 5.730 & 0.000 & Significant \\
\hline $\begin{array}{l}\text { Indirect Effect } \\
\text { Work Atmosphere (X) } \\
\text {-> Employee } \\
\text { Performance (Y) }\end{array}$ & 0.352 & 6.127 & 0.000 & Significant \\
\hline
\end{tabular}

Source: Attachment of SmartPLS 3 Output, data processed (2017)

Based on Tables 4 and 5, it can be explained as follows:

Work Atmosphere influences Employee Performance at the University of Dr. Soetomo Surabaya. This can be seen from the path coefficient which is positive at 0.454 with a 
statistical $\mathrm{T}$ value of 5.730, which means that is greater 1.96 with a value of $\mathrm{p}<0.05$. So the first hypothesis reads: "Allegedly the work atmosphere influences the performance of employees at the University of Dr. Soetomo Surabaya "is proven.

Work Atmosphere has an indirect effect on Employee Performance through University Employee Welfare Dr. Soetomo Surabaya. This can be seen from the path coefficient which is positive at 0.352 with a statistical $\mathrm{T}$ value of 6.127 , which means that is greater 1.96 with a value of $\mathrm{p}<0.05$. So the third hypothesis reads: "It is suspected that employee welfare is a mediating variable between the influence of the variable work atmosphere on the performance of employees at the University of Dr. Soetomo Surabaya "is proven.

\subsection{Discussion}

\subsubsection{The Effect of Work Atmosphere on Employee Performance at the University of Dr. Soetomo Surabaya}

Based on the tests that have been conducted, it is known that the Work Atmosphere has a significant positive impact on Employee Performance at the University of Dr. Soetomo Surabaya. This can be indicated by a T-statistic value of 5.730 greater than 1.96 with a value of $\mathrm{p}<0.05$.

There is a positive influence on the work atmosphere on employee performance at the University of Dr. Surabaya Soetomo is shown in the parameter coefficient value which shows a positive direction of 0.454 , which means the higher the conducive atmosphere of employee work, the higher the performance of employees at the University of Dr. Soetomo Surabaya.

The results of this study prove that there is a significant effect of the work atmosphere formed by the workplace (X1), facilities and job aids (X2), hygiene (X3), lighting (X4), tranquility (X5), and work relations between people there is a place (X6) on employee performance, where Lighting (X4) is the most dominant form of the work atmosphere, so that it can be said that leadership style has a dominant role in the work atmosphere in influencing employee performance.

The results of this study are in line with the study conducted by Susetyowati, et al [18] regarding "Evaluation of Administrative Performance of Employees in the University of Dr. Soetomo Surabaya", which shows that the work atmosphere/work atmosphere in each work unit is categorized as quite conducive and there are even several work units whose working atmosphere is so harmonious.

\subsubsection{Welfare Variables As A Mediation of the Effects of Work Atmosphere on Employee Performance at the University of Dr. Soetomo Surabaya}

Based on the tests that have been conducted, it is known that the Work Atmosphere gives a significant indirect positive effect on the University's Employee Performance Dr. Soetomo Surabaya. This can be indicated by a T-statistic value of 6.127 greater than 1.96 with a value of $\mathrm{p}<0.05$. There is an indirect effect of the work atmosphere on the University's employee performance. Surabaya Soetomo is shown in the parameter coefficient value which shows a positive direction of 0.352 , which means the more the level of the Work Atmosphere level, then indirectly will improve Employee Performance, due to the mediation of the University Employee Welfare variable Dr. Soetomo Surabaya.

The results of this study indicate that the work atmosphere has been able to directly or indirectly influence employee performance. In this case, it can be proven that there are variables that mediate between the Work Atmosphere and Employee Performance. The variable is employee welfare. Colleges that have high-quality standards will be able to 
influence employees to form a good work atmosphere that can improve employee performance through mediating employee welfare. This is in accordance with the results of a study conducted by Susetyowati, et al [18] regarding "Evaluation of Administrative Performance of Employees in the University of Dr. Soetomo Surabaya ", which shows that the work atmosphere/work atmosphere in each work unit is categorized as quite conducive and there are even some work units whose working atmosphere is so harmonious.

\section{Conclusion}

There is a significant positive impact on the work atmosphere on employee performance at the University of Dr. Soetomo Surabaya, and the magnitude of the influence of Work Atmosphere on employee performance by $45.4 \%$. There is a significant impact on employee welfare variables as a mediating variable between the influence of work atmosphere on employee performance at the University of Dr. Soetomo Surabaya, and the magnitude of the influence of employee welfare on employee welfare by $35.2 \%$.

\section{References}

[1] A. Suryana, H. Agustin, and M. Hidayat, "Identifying the victims of workplace cyberbullying among lecturers," J. Stud. Komun., vol. 3, no. 2, pp. 151-166, 2019.

[2] S. N. Alex, "Manajemen personalia," Manaj. Sumber Daya Manusia, Jakarta, Gholia Indones., 2000.

[3] G. Saydam, "Manajemen Sumber Daya Manusia: Suatu Pendekatan Mikro," Jakarta: Djambatan, 2005.

[4] A. P. Mangkunegara and A. Prabu, "Manajemen Sumber Daya Manusia Perusahaan (Cetakan ke-9)," Rosda. Bandung, 2009.

[5] V. Rivai and A. F. M. Basri, "Performance Appraisal, PT," Raja Graf. Persada Jakarta, 2005.

[6] R. Panuju, D. Susilo, and R. Sugihartati, "A Strategy for Competitive Broadcasting Radio Community Networking in Tulungagung, Indonesia," 2018.

[7] R. L. Mathis and J. H. Jackson, "Manajemen sumber daya manusia, edisi kesepuluh," Terjem. Diana Angelica, Jakarta Selemba Empat, 2006.

[8] G. Dessler, "Manajemen Sumber Daya Manusia Jilid 2," Jakarta PT. Indeks, 2006.

[9] F. Cardoso Gomes, "Manajemen Sumber Daya Manusia," Penerbit Andi, Yogyakarta, 2003.

[10] M. S. P. Hasibuan, "Manajemen Sumber Daya Manusia: Jakarta, Indonesia: PT,” Bumi Aksara, 2008.

[11] S. Suprayitno, "Pengaruh disiplin kerja, lingkungan kerja dan motivasi kerja terhadap kinerja karyawan,” J. Manaj. sumber daya Mns., vol. Vol. 2, no. No. 1, pp. 23 - 34, 2007.

[12] Nogra, "Pengaruh Motivasi Kerja, Kepemimpinan dan Budaya Organisasi terhadap Kinerja Karyawan di PT. Angkasa Pura I Bandar Udara EI Tari Kupang Nusa Tenggara Timur," Universitas Mercu Buana, 2012.

[13] N. K. Malhotra, "Marketing Research: An Applied Orientation.(4thedn) Pearson Education," Inc New Jersey, p. 35, 2004.

[14] I. Swastha, Basu, Manajemen Pemasaran Modern. 2014.

[15] M. V De Leon, "Factors influencing behavioural intention to use mobile banking among retail banking clients," J. Stud. Komun., vol. 3, no. 2, pp. 118-137, 2019. 
[16] A. Ferdinand, "Metode penelitian manajemen: Pedoman penelitian untuk penulisan skripsi." Tesis, dan Disertasi Ilmu Manajemen. Semarang: Badan Penerbit Universitas ..., 2006.

[17] H. S. Riduwan, "Pengantar Statistika Untuk Penelitian: Pendidikan," Sos. Komun. Ekon. dan Bisnis, Alf. bandung, 2007.

[18] dkk Susetyowati, Evaluasi Kinerja Karyawan Administrasi di Lingkungan Universitas Dr. Soetomo Surabaya. Surabaya: Universitas Dr. Soetomo, 2016. 